\title{
Sudden cardiac arrest as first symptom of a benign cardiac tumor growth
}

\author{
Natalia Rivero Jiménez ${ }^{\mathrm{a}, *}$, Marta Ortega Molina ${ }^{\mathrm{a}}$, Montserrat Bret-Zurita ${ }^{\mathrm{b}}$, \\ Ángel Aroca Peinado ${ }^{c}$, Federico Gutiérrez-Larraya Aguado ${ }^{a}$
}

a Department of Pediatric Cardiology, La Paz Hospital, Madrid, Spain

b Department of Pediatric Radiology, La Paz Hospital, Madrid, Spain

c Department of Pediatric Cardiovascular Surgery, La Paz Hospital, Madrid, Spain

Received 30 October 2016; accepted 20 June 2017

Available online 10 October 2017

\section{KEYWORDS \\ Tumors; \\ Pediatrics; \\ Cardiac arrest}

\section{PALABRAS CLAVE}

Tumores;

Pediatría;

Parada cardíaca

\begin{abstract}
Primary cardiac tumors are rare, especially in the pediatric age. Most of them are benign in the sense they are not invasive. However, benign tumors maintain the potential for serious illness related to significant hemodynamic compromise or life-threatening dysrhythmias. We present the case of an infant with an initial diagnosis of cardiac rhabdomyoma who suffered ventricular arrhythmia and cardiac arrest. He suffered irreversible severe neurologic sequelae, due to his prolonged cardiopulmonary arrest and was finally diagnosed of cardiac fibroma. Good arrhythmia control was obtained after an extensive partial surgical resection of the tumor. This case highlights the importance of arrhythmia burden in this condition. A correct diagnosis based essentially in different imaging modalities and closer clinical and rhythm follow up could have avoided this ominous event.

(c) 2017 Sociedad Colombiana de Cardiología y Cirugía Cardiovascular. Published by Elsevier España, S.L.U. This is an open access article under the CC BY-NC-ND license (http:// creativecommons.org/licenses/by-nc-nd/4.0/).
\end{abstract}

\begin{abstract}
Muerte súbita como primer síntoma de crecimiento de tumor cardíaco benigno
Resumen Los tumores cardíacos primarios son raros, especialmente en la edad pediátrica. La mayoría de ellos son benignos, en el sentido de que no son invasivos. Sin embargo, los tumores benignos tienen el potencial para producir enfermedades graves que pueden causar compromiso hemodinámico significativo o arritmias potencialmente letales. Se presenta el caso de un niño con un diagnóstico inicial de rabdomioma cardíaco, quien sufrió una arritmia ventricular y una parada cardíaca. Tuvo secuelas neurológicas severas irreversibles debido al tiempo prolongado en parada cardiorrespiratoria y se le diagnosticó finalmente fibroma cardíaco. Se obtuvo un
\end{abstract}

\footnotetext{
* Corresponding author.

E-mail address: natalia17rj@hotmail.com (N. Rivero Jiménez).
} 
buen control de las arritmias después de una extensa resección parcial del tumor. Este caso pretende subrayar la importancia del riesgo de aparición de arritmias en esta situación. El diagnóstico correcto basado fundamentalmente en el uso de distintas modalidades de imagen y el seguimiento clínico y arritmológico, podrían haber evitado este desenlace fatal.

(c) 2017 Sociedad Colombiana de Cardiología y Cirugía Cardiovascular. Publicado por Elsevier España, S.L.U. Este es un artículo Open Access bajo la licencia CC BY-NC-ND (http:// creativecommons.org/licenses/by-nc-nd/4.0/).

Primary cardiac tumors are rare, especially in the pediatric age. The incidence in this age group is approximately $0.17 \%$ in the echocardiographic database review at Boston Children's Hospital, ${ }^{1}$ which is similar to the incidence of $0.2 \%$ reported at the Hospital for Sick Children, Toronto. ${ }^{2}$

Most primary pediatric cardiac tumors are benign in the sense they are not invasive. Fewer than $10 \%$ of these primary tumors are malignant. ${ }^{3}$ However, benign tumors maintain the potential for serious illness related to significant hemodynamic compromise or life-threatening dysrhythmias.

Is presented a case of a patient diagnosed of a benign primary cardiac tumor who developed a serious complication and poor outcome in follow up.

\section{Case}

A two year-old infant with prenatal diagnosis of cardiac mass, who collapsed at home while playing. He was being followed since birth in a cardiology outpatient clinic with the diagnosis of benign cardiac rhabdomyoma. He suffered a cardiopulmonary arrest and was taken to the emergency department where advanced resuscitation maneuvers were practiced for $\mathbf{4 0}$ minutes. First documented cardiac rhythm was ventricular fibrillation. After initial stabilization and treatment, he was transferred to our centre for multidisciplinary treatment.

Chest $x$-ray demonstrated an increased cardiothoracic index $(0.70)$ with pulmonary congestion. 12-lead electrocardiogram showed unremarkable sinus rhythm with an average heart rate of $130 \mathrm{bpm}$, normal PR and QRS intervals, and QRS axis in $0^{\circ}$. There were symmetrical and deep T-wave inversions in the lateral precordial leads. Transthoracic echocardiography demonstrated a homogeneous intramural left ventricular mass in the free wall and apex, which involved the anterior papillary muscle, with no valvular incompetence nor mechanical left ventricular outflow or inflow obstruction. The image suggested a fibroma as the first diagnostic possibility (fig. 1). Cardiac magnetic resonance images revealed a $4.5 \times 4.8 \times 4.1 \mathrm{~cm}$, firm, well-demarcated intramural mass related to the anterior papillary muscle and the subendocardial free wall region of the middle and apical segments of the left ventricle. Late contrast-enhanced cardiac magnetic resonance images were acquired after gadolinium injection, showing a homogeneous and intense bright mass, suggesting the nature of fibroma (fig. 2). A slight global left ventricular systolic dysfunction was observed, with an ejection fraction of $55 \%$.

The patient had a severe irreversible neurological dysfunction due to a severe hypoxic ischemic encephalopathy secondary to the prolonged cardiac arrest. Given this situation, he was unable to swallow and a percutaneous gastrostomy was placed.

During admission, he presented episodes of non-sustained ventricular tachycardia as well as multiple episodes of different monomorphic sustained ventricular tachycardia. Ventricular tachycardia morphology suggested its origin from left ventricular apex, coinciding with cardiac tumor's location. Pharmacologic treatment was initiated with amiodarone and propranolol with poor control of the arrhythmia. The decision was taken to perform a complete surgical resection of the tumor (fig. 3). Finally, only an extensive partial tumor resection was undertaken due to technical

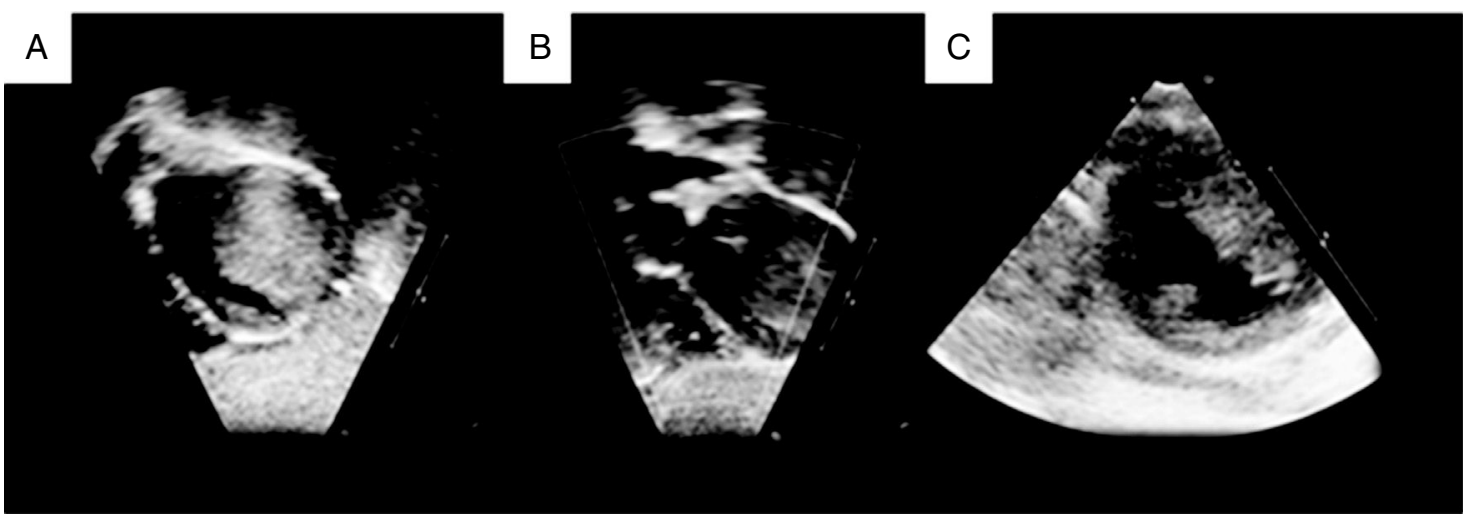

Figure 1 Two-dimensional echocardiogram in a 2-year-old child with a large left ventricular fibroma. A. Subcostal sagittal sweeps showing homogenous intramural mass extending from the left ventricular free wall into the cavity. B. Subcostal coronal sweeps revealing no left ventricular outflow obstruction. C. Parasternal short-axis shows tumor involving the anterior papillary muscle. 


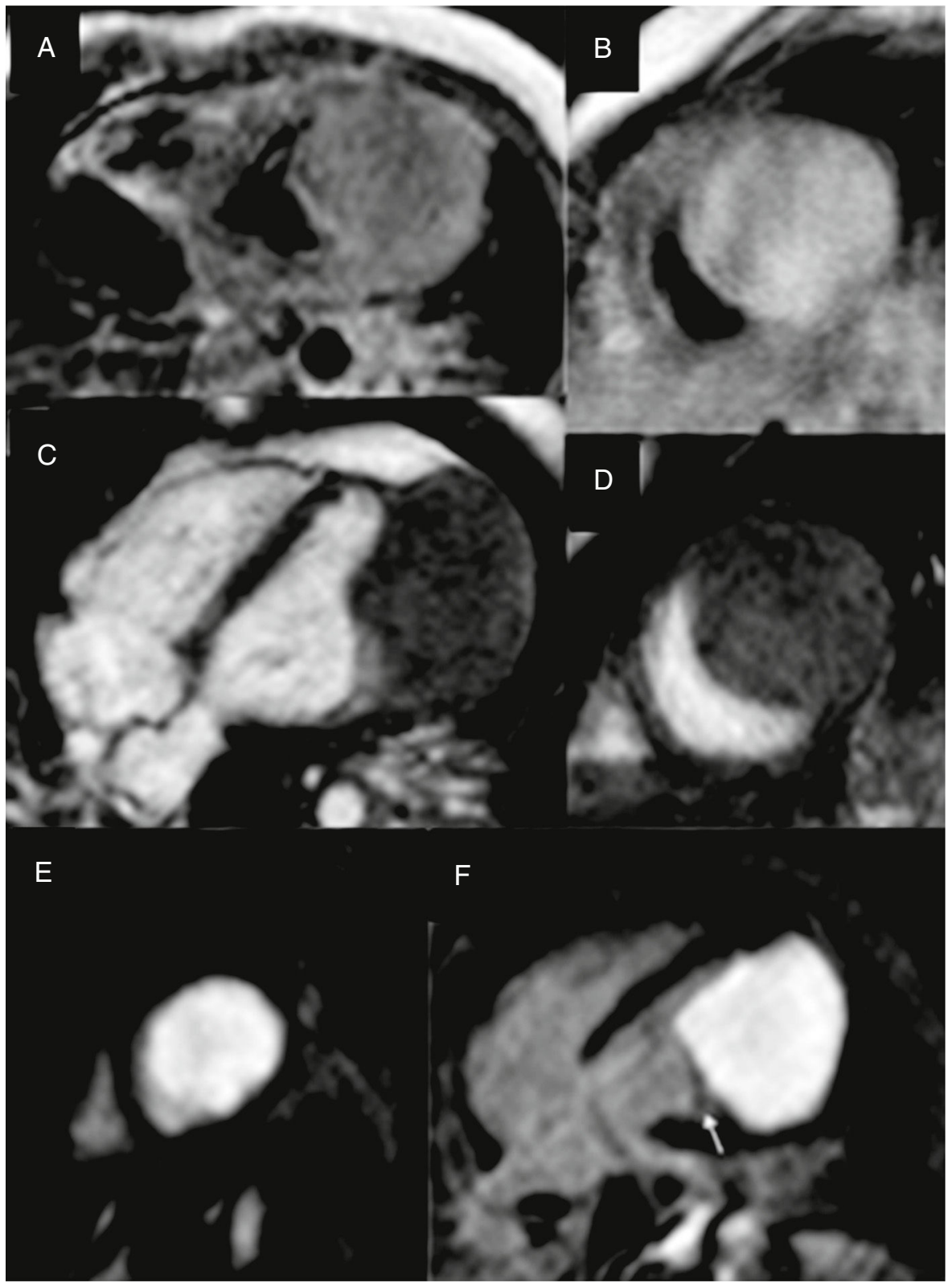

Figure 2 Cardiac magnetic resonance imaging. A. Aaxial T1-weighted spin- echo image; B. DP-weighted spin -echo image; C. 4 chamber view gradient-echo cine; D. Short axis gradient-echo cine. An isointense solid mass is observed in T1, slightly hyperintense relative to muscle on $\mathrm{T} 2$ and gradient-echo sequences, located in left ventricular lateral wall. E, F. Late contrast-enhanced cardiac magnetic resonance images after gadolinium injection in short axis $(E)$ and four chamber view $(F)$, showing a homogeneous mass. Lateral wall and apex myocardium can be appreciated, closely to the mass on its lateral, top and bottom margins and papillary muscle (arrow).

risks of damaging the mitral valve. Biopsy pathological examination confirmed the diagnosis of fibroma. The surgery was uneventful and good arrhythmia control was achieved.

Isolated low frequency monomorphic ventricular ectopy were observed at holter monitoring before discharge. Echocardiographic evaluation showed an apical left ventricular aneurysm with preserved left ventricular function. In follow up, the patient has been free of cardiac symptoms and free of significant arrhythmia.

\section{Discussion}

Cardiac fibroma could be considered a benign condition, but slow and continual growth has been reported and may cause significant morbidity related to obstruction, infiltration, thromboembolism, arrhythmias or even death. Clinical significant arrhythmia can occur in up to $24 \%$ of pediatric patients with cardiac tumors, being fibromas the subtype with the highest risk, with risk of ventricular tachycardia exceeding $50 \% .{ }^{4}$ Special attention must 


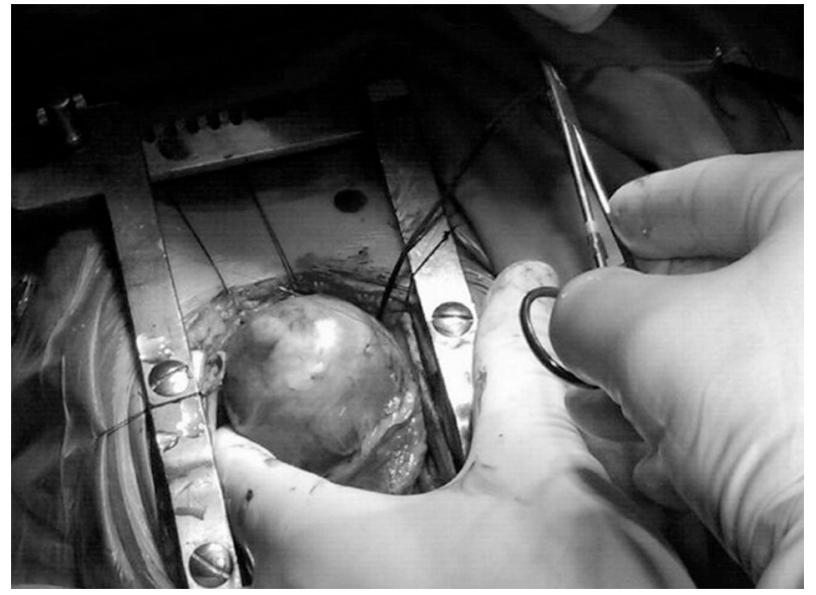

Figure 3 Intraoperative view: large mass protruding from the left ventricular apex.

be taken then to arrhythmia in this condition. A rapid and precise tumor diagnosis and close follow up could be essential to prevent an ominous outcome as in the case presented.

Diagnosis is based in different imaging modalities. Echocardiography has been and remains an invaluable tool for cardiac evaluation. It permits a rapid and cost-effective evaluation of cardiac masses. ${ }^{5}$ The typical echocardiographic appearance of a fibroma is a discrete often obstructive, echogenic, noncontractile mass ranging in size from 1 to $10 \mathrm{~cm}$ in diameter in a ventricular wall. ${ }^{6}$ They are single, bright, intramural masses within the interventricular septum or the left ventricular free wall. ${ }^{7-9}$ In appearance it may mimic hypertrophic cardiomyopathy or ventricular septal hypertrophy. ${ }^{10}$ Macroscopically, they are characteristically solitary, white, firm, nonencapsulated, intramural tumors that involve the left ventricular free wall, apex or interventricular septum. ${ }^{11,12}$ Less frequently, they are multiple and invade the right ventricular free wall, atrial septum, or atrial free wall. ${ }^{11}$ Extensive intramural fibromas can encroach and obliterate the intracavitary space. ${ }^{11}$ Although rare, intracavitary fibromas have been reported, ${ }^{11}$ occurring either as a single pedunculated mass ${ }^{11}$ or attached by a broad base to the endocardium. ${ }^{7}$ They may be echocardiographically differentiated from rhabdomyomas by the presence of calcification and cystic degeneration; ${ }^{13}$ also with strain imaging, fibromas are shown not to be compressed during the cardiac cycle. ${ }^{14}$

Computed tomography and cardiac magnetic resonance allow for better tissue characterization. ${ }^{5}$ At Computed tomography, fibromas appear as homogenous masses with soft tissue attenuation that may be either infiltrative or sharply marginated. Calcification is often seen. ${ }^{15}$ Cardiac Magnetic Resonance can help to assess tumor location, size, morphology, borders and most importantly, provide definite tumor characterization while avoiding radiation. Cardiac magnetic resonance has been shown to correctly classify tumors as benign or malignant in $95 \%$ of cases, when comparing with histology as the gold standard. ${ }^{16}$ On cardiac magnetic resonance, fibromas are strong hyperenhancement on myocardial delayed enhancement imaging with or without a hypoenhancing (dark) core. They have a heterogeneous appearance on T1- and T2-weighted turbo (fast) spin echo sequences with variable areas of slightly hypo- or hyperintense areas. ${ }^{17}$ It also evaluates the extent of myocardial infiltration as well as the relationship of the tumor mass to coronary artery anatomy. ${ }^{13,15}$

Regular frequent clinical assessments and Holter monitoring could be necessary in order to determine arrhythmia burden. Clinically significant ventricular arrhythmias are common and should be promptly evaluated. ${ }^{4}$ The baseline electrocardiogram may show QRS axis deviation, atrial enlargement, or ventricular hypertrophy, ${ }^{7,8,12}$ and invariably present ST-T wave abnormalities consistent with strain or ischemia ${ }^{7,8,12}$ typically in left lateral leads. If high degree ventricular ectopy or non-sustained ventricular tachycardia is present, treatment should be preferably encountered.

Optimal management strategies for pediatric patients with cardiac tumors remain unclear, particularly when serious arrhythmias are present. ${ }^{4}$ Surgical excision of such tumors has been reported to be a highly effective management option, being curative and lifesaving therapy. ${ }^{4}$ Surgery for cardiac tumors in pediatric age carries an acceptable mortality risk ${ }^{18}$ and appears to be the optimal treatment in patients with symptomatic resectable tumours. ${ }^{19}$ In patients with severe tumor involvement, subtotal excision has also shown good long term survival. ${ }^{19}$ The role of surgery in patients with asymptomatic tumors that could remain dormant for many years and even regress is less clear. ${ }^{20}$ However, because of fatal arrhythmias, surgery is often recommended despite absence of symptoms. Even transplantation is considered for large symptomatic unresectable tumors. ${ }^{15}$

In conclusion, this case report shows how a benign cardiac tumor could have devastating consequences. Clinicians should be aware of arrhythmia risks in cardiac tumors in children, especially in fibromas. A correct tumor type diagnosis based essentially in different imaging modalities, and closer clinical and rhythm follow up could have avoided the event and severe neurologic sequelae.

\section{Ethical disclosures}

Protection of human and animal subjects. The authors declare that no experiments were performed on humans or animals for this study.

Confidentiality of data. The authors declare that no patient data appear in this article.

Right to privacy and informed consent. The authors declare that no patient data appear in this article.

\section{Financial disclosure}

None.

\section{Conflict of interest}

Any. 


\section{References}

1. Marx GA, Moran AM. Cardiac tumors. In: Allen HD, Adams FH, Moss AJ, editors. Heart disease in infants, children and adolescents, including the fetus and young adult. Philadelphia, PA: Lippincott Williams \& Wilkins; 2001. p. 1432-45.

2. Freedom RM, Lee KJ, Macdonald C, Taylor G. Selected aspects of cardiac tumors in infancy and childhood. Pediatr Cardiol. 2000;21:299-316.

3. Chan HS, Sonley MJ, Moes CAF, Daneman A, Smith CR, Martin DJ. Primary and secondary tumors of childhood involving the heart, pericardium and great vessels: A report of 75 cases and review of the literature. Cancer. 1985;56:825-36.

4. Miyake CY, Del Nido PJ, Alexander ME, Cecchin F, Berul CI, Triedman JK, et al. Cardiac tumors and associated arrhythmias in pediatric patients, with observations on surgical therapy for ventricular tachycardia. J Am Coll Cardiol. 2011;58:1903-9.

5. Auger D, Pressacco J, Marcotte F, Tremblay A, Dore A, Ducharme A. Cardiac masses: an integrative approach using echocardiography and other imaging modalities. Heart. 2011;97:1101-9.

6. Burke A, Virmani R. Tumors of the heart and great vessels. Atlas of Tumor Pathology. Washington, DC: Armed Forces Institute of Pathology; 1996. p. 1-98.

7. Kutayli F, Malouf J, Slim M, Mufarrij A, Hatem J. Cardiac fibroma with tumor involvement of the mitral valve: Diagnosis by crosssectional echocardiography. Eur Heart J. 1988;9:563-6.

8. Filiatrault M, Béland MJ, Neilson KA, Paquet M. Cardiac fibroma presenting with clinically significant arrhythmias in infancy. Pediatr Cardiol. 1991;12:118-20.

9. Brown IW, McGoldrick JP, Robles A, Curella GW, Gula G, Ross DN. Left ventricular fibroma: Echocardiographic diagnosis and successful surgical excision in three cases. J Cardiovasc Surg. 1990;31:536-40

10. Bruce CJ. Cardiac tumors. In: Otto CM, editor. The Practice of Clinical Echocardiography. Philadelphia: WB Saunders; 2007. p. 1108-37.
11. Marín-García J, Fitch CW, Shenefelt RE. Primary right ventricular tumor (fibroma) simulating cyanotic heart disease in a newborn. J Am Coll Cardiol. 1984;3:868-71.

12. Williams WG, Trusler GA, Fowler RS, Scott ME, Mustard WT. Left ventricular myocardial fibroma: A case report and review of cardiac tumors in children. J Pediatr Surg. 1972;7:324-8.

13. Moss Marx GR, Moran AM. Cardiac Tumors. In: Allen HD, Driscoll DJ, Shaddy RE, et al., editors. Moss and AdamsH́eart Disease in Infants, Children and Adolescents, including the Fetus and Young Adult. Philadelphia, PA: Lippincott Williams \& Wilkins; 2008. p. 1479-95.

14. Ganame J, D'hooge J, Mertens L. Different deformation patterns in intracardiac tumors. Eur J Echocardiogr. 2005;6: 461-4.

15. Bruce CJ. Cardiac tumours: diagnosis and management. Heart. 2011;97:151-60.

16. Fussen S, De Boeck BW, Zellweger MJ, Bremerich J, Goetschalckx K, Zuber $M$, et al. Cardiovascular magnetic resonance imaging for diagnosis and clinical management of suspected cardiac masses and tumours. Eur Heart J. 2011;32: 1551-60.

17. Beroukhim RS, Prakash A, Buechel ER, Cava JR, Dorfman AL, Festa $\mathrm{P}$, et al. Characterization of cardiac tumors in children by cardiovascular magnetic resonance imaging: a multicenter experience. J Am Coll Cardiol. 2011;58:1044-54.

18. Paladino MA, Vida VL, Boccuzzo G, Tonello M, Sarris GE, Berggren $\mathrm{H}$, et al. Surgery for primary cardiac tumors in children: early and late results in a multicenter European Congenital Heart Surgeons Association study. Circulation. 2012;126:22-30.

19. Cho JM, Danielson GK, Puga FJ, Dearani JA, McGregor CG, Tazelaar HD, et al. Surgical resection of ventricular cardiac fibromas: early and late results. Ann Thorac Surg. 2003;76:1929-34.

20. Burke AP, Rosado-de-Christenson M, Templeton PA, Virmani R. Cardiac fibroma: clinicopathologic correlates and surgical treatment. J Thorac Cardiovasc Surg. 1994;108:862-70. 